DOI: $10.19195 / 0137-1134.106 .6$

\title{
POJECCIE BEZPIECZEŃSTWA W OBOWIĄZUJĄCYM SYSTEMIE PRAWA - KILKA REFLEKSJI NA TEMAT NORMATYWIZACJI PROBLEMATYKI BEZPIECZEŃSTWA
}

\section{PRAWNICZE I PRAWNE KONOTACJE TERMINOLOGICZNE}

Bezpieczeństwo jest terminem prawnym, walor pojęcia (także w znaczeniu koherentnym z problematyką konferencji) zyskuje już jednak w języku prawniczym. Semantyka tego terminu o bezspornych konotacjach interdyscyplinarnych ciągle stanowi przedmiot licznych analiz prowadzonych w ramach różnych dziedzin nauki i właściwych im dyscyplin naukowych (przede wszystkim — o społecznej proweniencji). Już poprzestanie na perspektywie właściwej dorobkowi nauki prawa administracyjnego daje wyobrażenie o jego wieloznaczności (znajdującej często potwierdzenie także na płaszczyźnie terminologicznej), eksponując zarówno różnorodność uwarunkowań tej wartości (tego stanu, zjawiska czy też celu, zadania), jak i właściwych każdemu z tych ujęć atrybutów ${ }^{1}$. A zatem, mając na uwadze wypracowane doktrynalnie ustalenia i z zamiarem ich syntetycznego

${ }^{1}$ Warto w tym kontekście zacząć od przypomnienia publikacji dokumentującej wcześniejszą konferencję (która miała miejsce w dniu 1 czerwca 2009 r.) o podobnym profilu tematycznym, organizowaną przy współudziale kooperującego z praktyką administracyjną Wydziału Prawa, Administracji i Ekonomii UWr, a w szczególności dwa artykuły: J. Boć, O bezpieczeństwie wewnętrznym, [w:] Bezpieczeństwo wewnętrzne w działaniach terenowej administracji publicznej, red. A. Chajbowicz, T. Kocowski, Wrocław 2009, s. 19-28; A. Chajbowicz, Bezpieczeństwo a pojęcia zbliżone, [w:] Bezpieczeństwo wewnętrzne w działaniach terenowej administracji publicznej, s. 37-50. Z najnowszych publikacji o takim przeznaczeniu należy wskazać między innymi następujące pozycje: Z. Duniewska, Bezpieczeństwo publiczne a pozycja jednostki, [w:] Jednostka wobec działań administracji publicznej, red. E. Ura, E. Feret, S. Pieprzny, Rzeszów 2016, s. 103-110; J. Filaber, Ochrona bezpieczeństwa publicznego w gminie, Warszawa 2016, s. 21-48. Oczywiście trzeba też wspomnieć o klasycznych opracowaniach zajmujących się tego rodzaju problematyką, np. S. Pieprzny, Ochrona bezpieczeństwa i porządku publicznego w prawie administracyjnym, Rzeszów 2007, s. 13-45. Zob. jeszcze publikacje, do których odwoływano się we wspomnianych opracowaniach. 
wykorzystania oraz ewentualnego wzbogacenia, w kwestiach terminologicznych zasadne wydaje się poprzestanie na następujących konstatacjach:

a) Brak legalnej definicji bezpieczeństwa (publicznego/wewnętrznego/powszechnego itp.) ma więc obiektywną zasadność. Wielości zastosowań bezpieczeństwa (czyniącej z tego przedmiotu poznania sui generis topos społeczny, a w konsekwencji - i prawny) towarzyszy bowiem różnorodność jego atrybutów, przesądzając o relatywizacji ustaleń dotyczących zarówno kwestii terminologicznych, jak i pojęciowych. Nie bez przyczyny zatem w analizach podejmujących tego rodzaju problematykę pojawiają się sformułowania typu:

— „Pełne i uniwersalne uchwycenie tego, co mieści w sobie to pojęcie nie jest łatwe, jeśli w ogóle wykonalne. Jest ono nieostre i względne, nierzadko koniunkturalne, uwikłane ideologicznie, częściowo stabilne, w części podlegające istotnym przeobrażeniom. To, co uznane jest za bezpieczeństwo publiczne, zależy od otaczającej nas rzeczywistości, w tym korespondujących z nią regulacji prawnych"2;

— „Uniwersalność znaczenia bezpieczeństwa i niebezpieczeństwa odpowiada bogatemu zróżnicowaniu przedmiotowemu obejmującemu długą listę zagrożeń, od wojny i terroryzmu zaczynając, na bezpieczeństwie żywnościowym, bezpieczeństwie nauczania w gimnazjum czy ochronie przed klęskami żywiołowymi kończąc"3;

— „Obraz pojęcia bezpieczeństwo publiczne [...] nie jest jednoznaczny. Przedmiot ochrony jest w zasadzie podobny. Widoczne są jednak różnice co do podmiotowego zakresu pojęcia bezpieczeństwo publiczne"4.

Nie ulega jednak wątpliwości, że tego rodzaju uwarunkowania nie wykluczają doktrynalnych identyfikacji, tyle że obarczonych nieuchronną relatywizacją i często dającym o sobie znać subiektywizmem. Wyprowadzanych w takich warunkach ustaleń (np. „To co stanowi wspólny mianownik definicji bezpieczeństwa publicznego, które formułowane były przez przedstawicieli doktryny [...], to kryterium braku zagrożeń dla swobodnego funkcjonowania obywatela, czyli przede wszystkim ochrona jego życia, zdrowia i mienia, a także kryterium niezakłóconego funkcjonowania organizacji państwowej i realizacja jej interesów"5), nie należy więc zbytnio absolutyzować. Każdorazowo trzeba bowiem pamiętać o na swój sposób pesymistycznym podejściu poznawczym, podsumowywanym konkluzjami typu „Pojęcie »bezpieczeństwo publiczne« znamionuje jego wysoki poziom ogólności połączony z brakiem przejrzystości”6.

b) W uzupełnieniu do często poruszanych $\mathrm{w}$ nauce prawa administracyjnego wątków etymologicznych (wskazujących na konotacje z łacińskim securitas ${ }^{7}$,

2 Z. Duniewska, op. cit., s. 105.

3 J. Boć, op. cit., s. 21.

4 A. Chajbowicz, op. cit., s. 40.

5 J. Filaber, op. cit., s. 35.

${ }^{6}$ Z. Duniewska, op. cit., s. 108.

7 A. Chajbowicz, op. cit., s. 38. 
czasami sięgających też i do etymologii tego wyrażenia ${ }^{8}$ ) warto zauważyć, że dominujący sposób definiowania bezpieczeństwa, zasadzający się na upatrywaniu jego kluczowych cech $\mathrm{w}$ atrybutach „stanu wolnego od zagrożeń, dającego poczucie pewności" 9 - daje asumpt do interesujących analiz o translatorskiej proweniencji. O ile bowiem w języku polskim termin „niebezpieczeństwo” jest słowotwórczo wtórny do zwrotu „bezpieczeństwo”, o tyle w języku rosyjskim jest odwrotnie: безопасность (bezpieczeństwo) opiera się na kontaminacji, której punktem wyjścia jest słowo опасность (niebezpieczeństwo). Inaczej rzecz ujmując, w ujęciu słowotwórczym pierwotnym rzeczownikiem jest bezpieczeństwo, a wyrazem złożonym, przeznaczonym do oznaczania desygnatów o przeciwstawnej do wyjściowej charakterystyce znaczeniowej — niebezpieczeństwo; w języku zaś rosyjskim mamy do czynienia z afiksacją o odwrotnym kierunku znaczeniowym - dodanie prefiksu „без” dopiero generuje stan pozbawiony niebezpieczeństw (zagrożeń, braku pewności). Pozostawiając kwestią otwartą zasadność upatrywania w odwrotnym przebiegu wykazanych tendencji słowotwórczych jakichś odniesień kulturowych ${ }^{10}$, warto zauważyć, że powyższe zestawienie inspiruje do postawienia pytania o chronologię faktyczną obu wymienianych stanów. Wydaje się jednak, że wielość ujęć i zastosowań problematyki bezpieczeństwa, jak również synergiczne relacje między prawem pozytywnym a przedmiotem jego regulacji i podmiotami prawa uniemożliwiają wyprowadzenie uniwersalnej konkluzji w tym zakresie. Z systemowego punktu widzenia wskazane jest zatem podejście elastyczne, uwzględniające wielość kombinacji możliwego przenikania się stanów bezpieczeństwa/niebezpieczeństwa. Trzeba też mieć na uwadze różnorodność i dynamikę zjawisk i procesów społecznych. Niemniej jednak nie będzie nadużyciem stwierdzenie opowiadające się za — summa summarum — przewagą, w warunkach prawidłowo funkcjonującego demokratycznego państwa prawnego (może nawet w typie dominacji), stanu/-ów bezpieczeństwa nad stanem/-ami niebezpieczeństwa. Nie ulega przy tym wątpliwości, że z perspektywy funkcji państwa i prawa stan bezpieczeństwa, ujmowany również jako kluczowa wartość i dobro wspólne ${ }^{11}$, stanowi punkt wyjścia - ewentualnie, w razie wystąpienia deficytu poczucia braku zagrożeń czy też odczuwania pewności — jako stan dojścia.

c) Zgodnie z przyjętymi założeniami tę część analizy uzupełnią dwa nawiązania do dokonanych już w nauce prawa administracyjnego ustaleń: jednego

8 A więc wskazujące, w kontekście kontaminacyjnym, na pochodzeniu od przyimka sine (bez) i rzeczownika cura (obawa, troska, niepokój) - J. Filaber, op. cit., s. 23.

9 Nota bene, perspektywa etymologiczna ograniczona do ewolucji języka polskiego wskazuje na to, że pierwotnie zwrot „bez pieczy/bezpieczny” rozumiano jako, między innymi „wolny od obaw, pewny, spokojny”, a contrario zaś — „niebezpieczny” jako „niepewny, zagrożony”.

10 Nie można jednak wykluczyć, że słowotwórcza pierwotność niebezpieczeństwa w języku rosyjskim może mieć uzasadnienie kulturowe, historyczne.

11 Zob. np. A. Pakuła, Bezpieczeństwo jako dobro wspólne (kilka uwag i refleksji), [w:] Bezpieczeństwo wewnętrzne w działaniach terenowej administracji publicznej, s. 29-36. 
o przeznaczeniu pierwotnie systematyzującym, drugiego — identyfikującego już bardziej liniowe znaczenia tego pojęcia. A zatem, po pierwsze, warto przypomnieć o wyróżnieniu przez J. Bocia trzech podstawowych ujęć pojęcia bezpieczeństwa ${ }^{12}$ :

— jako idei (,„która albo wyznacza, albo też nawet kształtuje treść przyszłych zachowań, albo potwierdza zgodność zachowań dotychczasowych z nią samą");

— jako motywacji podejmowania określonych działań; publicznych — w przypadku podmiotów administracji publicznej, prywatnych — w razie podejmowania działań o znaczeniu publicznym przez obywateli;

— jako nakazu, ,przymuszającego do nadania określonemu działaniu określonych kształtu i treści”.

Natomiast, bazując na kolejnej publikacji ze wspomnianej już konferencji, można dokonać, w warunkach optyki właściwej nauce prawa administracyjnego oraz nauce administracji, podziału na bezpieczeństwo w ujęciu ${ }^{13}$ :

- materialnym (przedmiotowym) rozumiane jako „stan rzeczywistości (stosunków społecznych), wolny od zagrożeń, dający poczucie pewności", docelowo zaś - jako prawnie chroniony stan ukierunkowany na zapobieganie normatywnie kwalifikowanym zagrożeniom oraz likwidację lub redukcję skutków takich zagrożeń, możliwy do osiągnięcia przede wszystkim dzięki realizacji funkcji właściwych policji administracyjnej;

- formalnym, koncentrującym uwage na ,zakresie zadań, kompetencji i form działania podmiotów odpowiedzialnych za kreowanie stosunków społecznych z zamiarem osiągania rezultatu w postaci ww. stanu";

— instytucjonalnym, preferującym ,zainteresowanie systemem podmiotów legitymowanych do aktywności wyróżnianej w ww. ujęciu formalnym, służącej osiąganiu stanu identyfikowanego w płaszczyźnie materialnej”.

\section{KONTEKST AKSJOLOGICZNY}

Aksjologiczny kontekst oraz wymiar bezpieczeństwa, jak również jego znaczenie są faktami notoryjnymi ${ }^{14}$, znajdując potwierdzenie w zasięgu $\mathrm{i}$ intensywności normatywizacji problematyki bezpieczeństwa (w każdym z trzech wyróż-

12 J. Boć, op. cit., s. 22.

13 P. Lisowski, Zadania powiatu w zakresie bezpieczeństwa, [w:] Bezpieczeństwo wewnętrzne $w$ działaniach terenowej administracji publicznej, s. 111.

${ }^{14}$ Mentalność i rangę tej problematyki podkreśla i eksponuje nomenklatura źródeł prawa zajmujących się zagadnieniami z tej dziedziny, np. w [podkreślenia - P.L.]:

— ustawie z dnia 24 sierpnia 1991 r. o ochronie przeciwpożarowej (Dz.U. z 2016 r., poz. 191, z późn. zm.; dalej: „u.o.poż.”): „Ochrona przeciwpożarowa polega na realizacji przedsięwzięć mających na celu ochronę życia, zdrowia, mienia lub środowiska przed pożarem, klęską żywiołową lub innym miejscowym z a g r o ż e n i e m” (art. 1 ab initio u.o.poż.); „Krajowy system ratowniczo-gaśniczy ma na celu ochronę życia, zdrowia, mienia lub środowiska poprzez: 1) walkę z pożarami lub innymi klęskami żywiołowymi; 2) ratownictwo techniczne; 
nionych znaczeń). Ze wskazanych już jednak przyczyn trudno - w systemowej perspektywie - oczekiwać wyczerpujących i kazuistycznych unormowań. Także dlatego, że często w tym zakresie dają o sobie znać materie niepoddające się jednoznacznej identyfikacji. Tego rodzaju konkluzji można zresztą przyznać bardziej uniwersalne znaczenie. Jak już bowiem zwracano uwagę, „normatywizacja wartości (rozumiana jako stan objęcia wartości zakresem

normowania prawa przedmiotowego/stan ich osadzenia w prawie) nie musi w pełni przesądzić o uwolnieniu od ryzyka poznawczego związanego z relatywistycznym zapatrywaniem na sposoby kreowania wartości. Nadawaniu poszczególnym z nich waloru terminów prawnych raczej nie towarzyszą definicje legalne. W konsekwencji, czynienie z nich pojęć odbywa się w już w ramach języka prawniczego — w warunkach charakterystycznych dla interpretacji pojęć nieostrych, w dodatku przy znacznym udziale norm pozaprawnych (na mocy norm odsyłających). Z tego powodu nie można zamknąc procesu normatywizacji w fazie stanowienia prawa (w znaczeniu formalnym). Nieuchronnie bowiem niezbędnym jego dopełnieniem są ustalenia - głównie pojęciowe - czynione w trakcie stosowania prawa ${ }^{15}$.

3) ratownictwo chemiczne; 4) ratownictwo ekologiczne; 5) ratownictwo medyczne" (art. 14 ust. 1 pkt 1-5 u.o.poż.);

— ustawie z dnia 24 sierpnia 1991 r. o Państwowej Straży Pożarnej (Dz.U. z 2016 r., poz. 603; dalej: „u.P.S.P.”): „Powołuje się Państwową Straż Pożarną jako zawodową, umundurowaną i wyposażoną w specjalistyczny sprzęt formację, przeznaczoną do wa $1 \mathrm{ki}$ z pożarami, klęskami żywiołowymi i innymi miejscowymi zagrożeniami” (art. 1 ust. 1 u.P.S.P.); „Do podstawowych zadań Państwowej Straży Pożarnej należy: 1) rozpoznawanie zagrożeń pożarowych i innych miejscowych zagrożeń; 2) organizowanie i prowadzenie akcji ratowniczych w czasie pożarów, klęsk żywiołowych lub likwidacji miejscowych zagrożeń” (art. 1 ust. 2 pkt 1-2 u.P.S.P.). Materia poddawana regulacji często wymaga też używania innych określeń dających wyobrażenie o ciężarze gatunkowym problematyki bezpieczeństwa, np. w art. 3 pkt 9 i 10 ustawy z dnia 26 kwietnia 2007 r. o zarządzaniu kryzysowym (Dz.U. z 2013 r., poz. 1166, z późn. zm.; dalej: „u.z.k.”) jest mowa o mapie zagrożenia (przedstawiającej „obszar geograficzny objęty zasięgiem zagrożenia z uwzględnieniem różnych scenariuszy zdarzeń”) oraz o mapie ryzyka (wskazującej ,potencjalnie negatywne skutki oddziaływania zagrożenia na ludzi, środowisko, mienie i infrastrukturę”); w przepisach działu Va (Ochrona przed powodzią) ustawy z dnia 18 lipca 2001 r. Prawo wodne (Dz.U. z 2015 r., poz. 469, z późn. zm.; dalej: „u.P.w.”) jest zaś mowa o: mapach zagrożenia powodziowego, mapach ryzyka powodziowego, planach zarządzania ryzykiem pow odziow ym; w przepisach ustawy z dnia 29 listopada 2000 r. Prawo atomowe (Dz.U. z 2014 r., poz. 1512, z późn. zm.; dalej: „u.P.a.”) posłużono się zaś określeniami typu ciężka aw aria, narażenie, narażenie wyjątkowe, zagrożenie (narażenie potencjalne) — zob. art. 3 pkt 2a, 15,16 i 53 .

15 J. Boć, P. Lisowski, Normatywizacja wartości w prawie administracyjnym, [w:] Wartości w prawie administracyjnym. V Krakowsko-Wrocławskie Spotkania Naukowe Administratywistów, red. J. Zimmermann, Warszawa 2015, s. 24-25. Wątek ten podsumowano wówczas także następującymi wnioskami: „Mamy więc do czynienia ze swego rodzaju paradoksem. Ranga problematyki wartości nie przekłada się na skalę i dokładność regulacji prawnej. Właściwe jej zagadnienia częściej bowiem stanowią kontekst dla postanowień prawa pozytywnego niż bezpośrednio wyrażony przedmiot regulacji. Jeśli zaś już dochodzi do ich normatywizacji, to prawodawca: pojęć;

— preferuje posługiwanie się terminami bez prawnopozytywnej identyfikacji właściwych im

- często wykorzystuje mechanizm norm odsyłających do norm pozaprawnych;

— bazuje na zwrotach nieostrych" — ibidem, s. 37-38. 
Stąd nie zaskakuje znaczny udział prawnie legitymowanych tytułów do dyskrecjonalnego administrowania w sferze bezpieczeństwa. Wśród nich zdają się dominować przepisy wykorzystujące pojęcia nieostre, co można zilustrować kilkoma przykładami [wyr. — P.L.]. Pierwszy dotyczy definicji legalnej klęski żywiołowej. Atrybuty tego zjawiska wyznacza się przez odwołanie się (m.in.) do takich kryteriów, jak zagrażanie skutków życiu i zdrowiu „dużej liczby osób, mieniu w wielkich rozmiarach albo środowisku na znacznych obszarach" ${ }^{\prime 6}$. Z kolei w art. 3 pkt 1 u.z.k. definiuje się sytuację kryzysową jako „sytuację wpływającą negatywnie na poziom bezpieczeństwa ludzi, mienia w znacznych rozmiarach lub środowiska, wywołującą znaczne ograniczenia w działaniu właściwych organów administracji publicznej ze względu na nieadekwatność posiadanych sił i środków"17. Przechodząc do regulacji o bardziej już liniowym zastosowaniu (finalnym przeznaczeniu), warto przywołać fragmenty unormowań art. 21 u.o.poż., w których — w sferze kierowania akcją ratowniczą - w „okolicznościach uzasadnionych stanem wyższej konieczności” wyposażono strażaków w prawo zarządzenia „udostępnienia pojazdów, środków i przedmiotów niezbędnych do akcji ratowniczej".

Jeżeli jeszcze uwzględnić niezbędność i dominujące znaczenie działań faktycznych ${ }^{18}$, na których ewidentnie spoczywa ciężar administrowania w sferze bezpieczeństwa, to nie ulega wątpliwości, że mamy w tym przypadku do czynienia z subtelną i wrażliwą materią — wymagającą odpowiednio wyważonej (między

16 Art. 3 ust. 1 pkt 1 ustawy z dnia 18 kwietnia 2002 r. o stanie klęski żywiołowej, Dz.U. z 2014 r., poz. 333, z późn. zm. (dalej: „u.s.k.ż.”).

17 Warto przypomnieć o tym, że wyrokiem Trybunału Konstytucyjnego z dnia 21 kwietnia 2009 r. (K 50/07, OTK-A 2009/4/51) pierwotną treść przepisu uznano za niezgodną z art. 2 i art. 31 ust. 3 Konstytucji Rzeczypospolitej Polskiej z dnia 2 kwietnia 1997 r. (Dz.U. Nr 78, poz. 483, z późn. zm.), w szczególności z powodu uchybiającej standardom poprawnej legislacji nieprecyzyjności niektórych określeń użytych wówczas do zdefiniowania sytuacji kryzysowej. Uzasadniono to, między innymi, w następujący sposób:

— „Pojęcie »więzów społecznych« jest znane przede wszystkim w naukach społecznych (socjologii, politologii, psychologii społecznej). Na gruncie prawa jest trudne do zaakceptowania, tym bardziej, że nawet w naukach społecznych nie ma jednolitej definicji tego pojęcia, jak również nie występuje jedna typologia »więzów społecznych«. Pojęcie to ze względu na swoją wieloznaczność nie może być akceptowane jako element definicji ustawowej. Wszystkie próby precyzyjnego określenia »więzów społecznych « należy traktować jako hipotezy badawcze o niewielkim znaczeniu dla analizy prawnej";

— „Ponadto, trudno jednoznacznie określić, na czym polegają »poważne«, a na czym »mniej poważne« zakłócenia w funkcjonowaniu instytucji publicznych i jaki charakter owe "zakłócenia« powinny mieć, aby dopuszczalne było zastosowanie rygorów ustawy o zarządzaniu kryzysowym. Użycie sformułowania »zakłócenie w funkcjonowaniu instytucji publicznych«, jako jednej z przesłanek uznania sytuacji zagrożenia za »sytuację kryzysową«, stwarza zbyt szeroki margines swobody interpretacyjnej. Można zatem przyjąć, że kolejny element definicji, zawartej w art. 3 pkt 1 ustawy, jest nieprecyzyjny i niemożliwy do zaakceptowania z punktu widzenia art. 2 Konstytucji”.

18 A więc form działania administracji publicznej ex defintione niepoddających się czy też wręcz nienadających się do precyzyjnej normatywizacji. 
imperatywem precyzji unormowania a potrzebami dyskrecjonalnego administrowania) regulacji prawnej, szczególnie jednak uzależnionej od fazy stosowania pra$\mathrm{wa}^{19}$. To w tej fazie funkcjonowania porządku prawnego ostatecznie kształtuje się bowiem treść norm prawnych, a reguły postępowania zyskują praktyczny wymiar. Każdorazowo w warunkach doprowadzonych już do konkretnych stosunków i sytuacji prawnych dochodzi do realnego wyznaczania przebiegu i skutków właściwych bezpieczeństwu w ujęciu materialnym, formalnym i instytucjonalnym ${ }^{20}$. Należy także mieć na uwadze, że — szczególnie w kluczowych momentach administrowanie w sferze bezpieczeństwa sprowadza się do działań władczych, często dochodząc do użycia form przymusu bezpośredniego ${ }^{21}$.

Co więcej, waga problematyki bezpieczeństwa zyskuje w niektórych przypadkach szczególny wymiar normatywny, znajdujący wyraz w ustanowieniu tak zwanych specustaw. Ostatnim tego przykładem jest ustawa z dnia 18 marca 2016 r. o szczególnych rozwiązaniach związanych z organizacją wizyty Jego Świątobliwości Papieża Franciszka w Rzeczypospolitej Polskiej oraz Światowych Dni

19 Nie należy też bagatelizować znaczenia sfery przestrzegania prawa.

${ }^{20}$ Co warte podkreślenia, waga problematyki bezpieczeństwa, w tym jej bezspornie podstawowe znaczenie dla potrzeb człowieka, przesądzają w wielu przypadkach o wyjątkowym podejściu prawodawcy do konotacji aksjologicznych, czego szczególnym przykładem są teksty rot ślubowań funkcjonariuszy formacji odgrywających kluczową rolę w zapewnianiu stanu bezpieczeństwa, co dokumentują następujące ich fragmenty [podkreślenie - P.L.]: ,świadom podejmowanych obowiązków strażaka, uroczyście ślubuję być ofiarnym i mężnym w ratowaniu zagrożonego życia ludzkiego i wszelkiego mienia — nawet z narażeniem życia" — art. 30 ust. 1 u.P.S.P.; „,́́wiadom podejmowanych obowiązków policjanta, ślubuję: służyć wiernie Narodowi, chronić ustanowiony Konstytucją Rzeczypospolitej Polskiej porządek prawny, strzec bezpieczeństwa Państwa i jego obywateli, nawet z narażeniem życia" - art. 27 ust. 1 ustawy z dnia 6 kwietnia 1990 r. o Policji ,Dz.U. z 2015 r., poz. 355, z późn. zm. Zob. także art. 33 ust. 1 ustawy z dnia 12 października 1990 r. o Straży Granicznej, Dz.U. z 2014 r., poz. 1402, z późn. zm.

21 Czasami rozwiązania przyjmują dość drastyczny wymiar, co dodatkowo uzmysławia złożoność zarówno uwarunkowań problematyki bezpieczeństwa, jak i przyjmowanych w tej materii rozwiązań. Do przykładów takich ekstremalnych zagadnień i odnoszonych do nich unormowań należy problematyka bezpieczeństwa ruchu lotniczego - in conreto treść przepisów art. 18b ustawy z dnia 12 października 1990 r. o ochronie granicy państwowej (obecnie: Dz.U. z 2015 r., poz. 930 z późn. zm.). Co zaś szczególnie istotne, ich ewolucja świadczy o poszukiwaniu relatywnie mniej radykalnego rozwiązania. O ile bowiem w pierwotnym brzmieniu tych przepisów (a więc począwszy od dnia 19 sierpnia 2004 r.) możliwe było — w pewnych okolicznościach — zestrzelenie także obcego cywilnego statku powietrznego, na którym znajdowali się nie tylko terroryści, o tyle — w stanie prawnym obowiązującym od dnia 23 marca 2011 r. — jest to dopuszczalne tylko wtedy, gdy taki statek „nie posiada żadnych osób na pokładzie lub na pokładzie którego znajdują się wyłącznie osoby zamierzające użyć tego statku powietrznego jako środka ataku o charakterze terrorystycznym" — art. 18b ust. 2c. Intencje ustawodawcy są oczywiste (nota bene, warto przypomnieć o wpływie, jaki na wprowadzenie tych zmian wywarło postanowienie Trybunału Konstytucyjnego z dnia 28 października 2008 r. — S 4/08, OTK-A 2008/7/126). 
Młodzieży — Kraków 201622. Nota bene, wprowadzanie tego rodzaju regulacji ${ }^{23}$ trudno bezkrytycznie akceptować. Nie dość bowiem, że mogą świadczyć o niedoskonałości dotychczasowych (,normalnych”) regulacji prawnych ${ }^{24}$, to jeszcze często w swoich ekstraordynaryjnych rozwiązaniach bywają treści zdominowane interesem publicznym w stopniu zdającym się gubić proporcje adekwatne do potrzeb demokratycznego państwa prawnego (szczególnie w kontekście uwzględniania interesów indywidualnych) ${ }^{25}$.

\section{ADMINISTRACYJNOPRAWNA PRZESTRZEŃ NORMATYWIZACJI WARTOŚCI}

Z wielu powodów (między innymi z racji rozmiarów i zasięgu normowania, implikowanych zarówno przeznaczeniem, jak i niepomijalnością administracji publicznej) gałęzią prawa najintensywniej odnoszącą się do problematyki bezpieczeństwa jest prawo administracyjne. $\mathrm{Z}$ oczywistych względów dominują w tym zakresie unormowania prawa materialnego, znajdując liczne odniesienia w regulacjach procesowych. Co warte podkreślenia, wątek bezpieczeństwa wyraźnie też daje o sobie znać w ustrojowej części prawa administracyjnego.

Nie negując istotnego znaczenia materialnoprawnej normatywizacji problematyki bezpieczeństwa (z racji zorientowania na wyznaczanie praw i obowiązków administrowanych — także przez wskazywanie kryteriów wykorzystywanych przy kształtowaniu sytuacji prawnych) ${ }^{26}$, jak również przy pełnej świadomości

22 Dz.U. poz. 393 (dalej: „u.Ś.D.M.”). Jednym z głównych celów tej regulacji jest określenie szczególnych zadań organów administracji publicznej związanych z „organizacją wizyty Jego Świątobliwości Papieża Franciszka w Rzeczypospolitej Polskiej oraz Światowych Dni Młodzieży — Kraków 2016, zwanych dalej »Światowymi Dniami Młodzieży«, w szczególności w zakresie zapewnienia bezpieczeństwa i porządku publicznego oraz zabezpieczenia medycznego" - art. 1 pkt 1.

23 Do tej grupy należy zaliczyć (między innymi): ustawę z dnia 7 września 2007 r. o przygotowaniu finałowego turnieju Mistrzostw Europy w Piłce Nożnej UEFA EURO 2012 (Dz.U. z 2010 r. $\mathrm{Nr} 26$, poz. 133 z późn. zm.) czy też ustawę z dnia 10 kwietnia 2003 r. o szczególnych zasadach przygotowania i realizacji inwestycji w zakresie dróg publicznych (Dz.U. z 2015 r., poz. 2031).

${ }^{24}$ Co jednak ciekawe - utrzymywanych w obrocie prawnym.

25 „warto zauważyć, że arengi nie znajdują zastosowania w tzw. specustawach. Wydawać by się mogło, że w takich przypadkach okoliczności sprzyjają eksponowaniu podstaw aksjologicznych. Najwyraźniej jednak materie regulowane tego rodzaju aktami normatywnymi nie legitymują się tak wyraźnym i bezpośrednim wsparciem ze strony wartości - wystarcza im odwołanie się do celów i zadań publicznych oraz interesu publicznego. Trudno oprzeć się wrażeniu, że to za mało, by uzasadnić wprowadzanie takich regulacji typu lex specialis" - J. Boć, P. Lisowski, op. cit., s. 31.

${ }^{26}$ Np. art. 4 ust. 1 u.o.poż. (wyznaczający obowiązki właściciela budynku, innego obiektu budowlanego czy też terenu); art. 6-6d u.o.poż. (nakładające obowiązki spełnienia wymagań i uzyskania uzgodnień w zakresie ochrony przeciwpożarowej — w różnych fazach procesu inwestycyjnego); art. 9 u.o.poż. nakładający powszechny obowiązek zawiadamiania i powiadamiania o pożarze, klęsce żywiołowej lub innym miejscowym zagrożeniu; art. 25 ust. 1 u.o.poż. (wyznacza- 
wagi norm prawa procesowego (być może nawet w sposób bardziej ewidentny eksponowanej w ramach regulacji procedur dotyczących spraw z zakresu bezpieczeństwa) ${ }^{27}$, konieczne wydaje się zwrócenie uwagi na szczególne zaangażowanie w tego rodzaju problematykę norm prawa ustrojowego (i zasługującą na podobną ocenę rangę tych unormowań). Nie ogranicza się ono przy tym do licznych regulacji wyznaczających zadania i kompetencje administrujących w sferze materialnoprawnej ${ }^{28}$, ale - co charakterystyczne dla prawa ustrojowego - wiele uwagi poświęca sferze relacyjnie (dynamicznie) ujmowanej organizacji prawnej administracji publicznej. Co zaś szczególnie istotne, specyfika materii bezpieczeństwa sprzyja wprowadzaniu szczególnych (często mocno nietypowych) regulacji odnoszonych do sfery interakcji między administrującymi. Jako przykład wystarczy wskazać specyfikę sposobu oddziaływania określanego mianem zwierzchnictwa związanego z zespoleniem ${ }^{29}$, czy rozwiązania znajdujące umocowanie w u.s.k.ż., przede wszystkim w zakresie dość znacznie modyfikującym sytuację ustrojową organów administracji samorządowej ${ }^{30}$.

Prawnoadministracyjna normatywizacja problematyki bezpieczeństwa odgrywa zatem kluczową rolę, a inspirowana aksjologicznie ranga regulacji o takim przeznaczeniu sprzyja intensyfikowaniu prawnopozytywnego zaangażowania, często prowadzącemu do przyjmowania specyficznych rozwiązań prawnych.

jący uprawnienia kierującego działaniem ratowniczym); przepisy rozdziału 3 u.s.k.ż. wyznaczające zasady ograniczania wolności i praw człowieka i obywatela; art. 7 u.P.a. (nakładający obowiązki z zakresu wewnętrznego nadzoru nad przestrzeganiem wymagań ochrony radiologicznej); art. 881 ust. 1 u.P.w. (wprowadzający zakazy na obszarach szczególnego zagrożenia powodzią); art. 88n u.P.w. (określający zasady użytkowania wałów przeciwpowodziowych).

27 I to zarówno w sprawach materialnych (np. przepisy rozporządzenia Ministra Spraw Wewnętrznych i Administracji z dnia 24 października 2005 r. w sprawie czynności kontrolno-rozpoznawczych przeprowadzanych przez Państwową Straż Pożarną, Dz.U. Nr 225, poz. 1934; art. 5-9 i art. 11-13 ustawy z dnia 11 sierpnia 2001 r. o szczególnych zasadach odbudowy, remontów i rozbiórek obiektów budowlanych zniszczonych lub uszkodzonych w wyniku działania żywiołu, Dz.U. $\mathrm{Nr} 84$, poz. 906, z późn. zm.; nota bene kolejny przykład specustawy), jak i ustrojowych (np. art. 17 ust. 1 u.o.poż. dotyczący trybu tworzenia, przekształcania i likwidacji jednostek ochrony przeciwpożarowej, art. 49c u.P.S.P. określający zasady i tryb tworzenia oraz likwidacji grupy ratowniczej do wykonywania zadań poza granicami państwa).

28 Np. art. 10 ust. 1 , art. 12 ust. 5, art. 13 ust. 6 u.P.S.P. (wyznaczające zadania komendantów Państwowej Straży Pożarnej); art. 21b u.o.poż. (określający zadania własne powiatu w zakresie ochrony przeciwpożarowej); art. 88a-88k u.P.w. (dotyczące administrowania w sferze ochrony przed powodzią); art. 11 ust. 2, art. 13 ust. 2, art. 16 ust. 2, art. 18 ust. 2 u.z.k. (określające zadania krajowych, centralnych, wojewódzkich, powiatowych centrów zarządzania kryzysowego).

29 Więcej na ten temat P. Lisowski, Relacje strukturalne w polskim samorzadzie terytorialnym, Wrocław 2013, s. 127-142 (wraz z przywoływanymi tam publikacjami).

${ }^{30}$ Chodzi, w szczególności, o instytucję pełnomocników (art. 9 ust. 5 i art. 10 ust. 5 u.s.k.ż.) oraz dekretowanie podległości między organami różnych jednostek samorządu terytorialnego (art. 9 ust. 4 i art. 10 ust. 2 u.s.k.ż.); ponadto ibidem, s. 514-518. 


\section{GŁÓWNE PROBLEMY NORMATYWIZACJI WARTOŚCI W PORZĄDKU ADMINISTRACYJNOPRAWNYM}

Niebudzący wątpliwości wysoki (a często najwyższy) ranking problematyki bezpieczeństwa jest $\mathrm{w}$ istocie nieunikniony, zważywszy na silne konotacje aksjologiczne, wspierane równie mocnymi motywacjami społecznymi, zarówno w ujęciu zbiorowym, jak i indywidualnym. Funkcje państwa i prawa dodatkowo sprzyjają eksponowaniu takiego jej znaczenia. Należy jednak pamiętać o tym, że o ile stosunkowo łatwo o unifikację czy też chociażby harmonizację poglądów dla formułowania powyższej konstatacji na poziomie idei, ewentualnie jako dyrektywy kierunkowej, o tyle już zdecydowanie trudniej o podobną jednolitość preferencji, wyborów, postaw, ocen i odbioru względem przyjmowanych w tej materii ustaleń szczegółowych. Tymczasem, jak już na to wskazywano, bardzo często warunkiem sine qua non wykonywania zadań i realizacji celów właściwych bezpieczeństwu w ujęciu materialnym jest bazowanie na szczegółowych regułach postępowania, a więc i na bardzo punktowo prowadzonych działaniach.

W konsekwencji, zarówno procesowi normatywizacji problematyki bezpieczeństwa, jak i fazie kreowania porządku prawnego na etapie stosowania, wykonywania i przestrzegania norm prawnych - towarzyszą polemiki, gry i konflikty interesów ${ }^{31}$. Mając na względzie bezspornie znaczną społeczną wrażliwość przedmiotowej materii, należy podkreślić szczególną rolę, jaką w tym zakresie odgrywają mechanizmy prawnopozytywne służące wyważaniu punktów widzenia w ramach porządku prawnego. Co istotne, powinny być one zgodne z kontekstem i wymiarem demokratycznego państwa prawnego - nota bene nie „tylko” pod względem formalnym, lecz także merytorycznym. Bez respektowania tego rodzaju uwarunkowań i właściwego im przesłania porządek prawny szybko może stać się zakładnikiem kontrowersyjnej aksjologii, czy też wręcz sługą antywartości.

Bezpieczeństwo jest zarazem celem i uzasadnieniem administrowania, nie może być jednak aksjomatycznym pretekstem do sprawowania władzy publicznej — zarówno na etapie stanowienia prawa, jak i w fazie jego stosowania czy wykonywania (przestrzegania). Także z racji nieuchronnych i silnych związków z policją administracyjną (czy też z funkcją reglamentacyjną). Właściwy tym funkcjom

31 Na różnych poziomach i etapach porządku prawnego, zob. np. dyskusje prowadzone na etapie prac nad ustawą z dnia 10 czerwca 2016 r. o działaniach antyterrorystycznych (Dz.U. poz. 904), których swego rodzaju podsumowaniem był apel RPO do Prezydenta RP o poddanie jej kontroli prewencyjnej Trybunału Konstytucyjnego — z powodu nieproporcjonalności przyjętych rozwiązań prawnych między innymi w zakresie ograniczeń wolności zgromadzeń czy też w związku z wprowadzeniem możliwości blokowania treści w internecie), czy też sprawy administracyjne i sądowoadministracyjne dotyczące hałasu emitowanego przez syreny alarmowe. Powodów do kontestacji można też upatrywać w art. 24 ust. 3 u. Ś.D.M., zgodnie z którym „W okresie od dnia 17 lipca 2016 r. do dnia 3 sierpnia 2016 r. w zakresie operacji lotniczych obejmujących starty i lądowania w porze dziennej i nocnej na lotniskach użytku publicznego nie stosuje się ograniczeń wynikających z wymagań w zakresie ochrony środowiska przed hałasem". 
administracji publicznej konglomerat celów, zadań, metod i form działania potrzebuje więc dobrze skonstruowanego i odpowiednio funkcjonującego systemu kontroli nad normatywizacją problematyki bezpieczeństwa oraz instytucjonalnymi, funkcjonalnymi i materialnymi przejawami praktyki administracyjnej w tym zakresie. Nie należy też zapominać o fundamentalnym znaczeniu, jakie dla funkcjonowania prawidłowego ${ }^{32}$ modelu porządku prawnego w sferze bezpieczeństwa ma (pierwotnie i prewencyjnie) respektowanie kanonicznego wręcz założenia dla organizacji i funkcjonowania państwa i prawa, a więc zasada trójpodziału władzy publicznej.

Jakiekolwiek uchybianie tego rodzaju paradygmatom grozi patologiami o trudnych do oszacowania skutkach — chodzi przecież o materię dotyczącą różnych aspektów jednej z najważniejszych potrzeb człowieka. Bez respektowania powyższych wymogów unormowania dotyczące problematyki bezpieczeństwa mogą, nomen omen, niebezpiecznie oddalić się od właściwej (a więc między innymi odpowiednio zidentyfikowanej i wyważonej) aksjologii, legitymując podobnie ocenianą praktykę administracyjną. Co ciekawe, dla łacińskiej securitas przewidziano też znaczenie „zbytnia pewność siebie”. Ten kontekst semantyczny dobrze obrazuje zagrożenia kreowania porządku prawnego w sferze bezpieczeństwa w warunkach uchybiających powyższym kanonom. A przecież, jak wykazano, problematyka bezpieczeństwa jest już de domo wystarczająco wymagająca i skomplikowana.

\section{PODSUMOWANIE}

Trudno więc przecenić znaczenie kwestii normatywizacji problematyki porządku prawnego. Jakość regulacji prawnej w tym zakresie, wymagająca przy tym znalezienia odpowiedniego balansu między uwarunkowaniami sprzyjającymi przyzwalaniu na uprawnienia dyskrecjonalne a potrzebą stanowienia prawa niebudzącego wątpliwości interpretacyjnych, pierwotnie determinuje bowiem praktykę administracyjną w sferze bezpieczeństwa. Summa summarum to jednak faza stosowania (wykonywania, przestrzegania) prawa daje realny obraz stanu bezpieczeństwa. Zważywszy zaś na znaczny udział władczych form działania administracji publicznej, w tym o atrybutach działań faktycznych, szczególnego znaczenia nabiera fachowość funkcjonariuszy administrujących. Nie ulega bowiem wątpliwości, że to ten zakres bezpieczeństwa w ujęciu formalnym stanowi kluczowy moment starań o właściwy stan z punktu widzenia materialnie rozumianego bezpieczeństwa. Co więcej, docelowo - w większości przypadków — polega na oddziaływaniu materialnoprawnym. A zatem wpływając na sytuacje prawne administrowanych, bezpośrednio też kształtuje społeczny odbiór administrowania.

32 Także (a może przede wszystkim) z aksjologicznego punktu widzenia. 
W dodatku w sferze o podstawowym znaczeniu dla władzy i administrowanych. Świadomość znaczenia tego rodzaju synergicznych związków bezspornie powinna towarzyszyć każdej ze sfer porządku prawnego.

\section{THE NOTION OF SECURITY IN THE BINDING LEGAL SYSTEM - A FEW REMARKS ON THE NORMATIVISATION OF SECURITY ISSUES}

\section{Summary}

The paper demonstrates that the notion of security is a lawyers' (and not legal) concept, and explains why it is so. It also introduces the basic classifications of security understood from both legal and lawyers' perspectives. In addition to that, the key determinants in the process of normative regulation of security are identified. The paper concludes with the analysis of basic difficulties and threats which can occur when the issue of security is being incorporated into the legal order. 